\title{
Thoraco- Omphalo-Ischiopagus Tripus Conjoined Twins: Report of a Case
}

Naser Kamalian', Shapour Shirani ${ }^{2 *}$ and Maryam Soleymanzadeh ${ }^{3}$

${ }^{1}$ Associate professor of Pathology, Department of Pathology, Shariati Hospital, University of Medical Sciences, North Kargar Street, Shariati hospital, Tehran, Iran ${ }^{2}$ Assistant professor of Radiology, Department of Radiology, Tehran Heart Center, Tehran University of Medical Sciences, North Kargar Street, Tehran Heart Center, Tehran, Iran

${ }^{3}$ Research Assistant, Research Department, Tehran Heart Center, Tehran University of Medical Sciences, North Kargar Street, Tehran Heart Center, Tehran, Iran

\begin{abstract}
The frequency of thoraco- omphalo-ischiopagus tripus or conjoined twins (CT) is quite rare of mozygotic twinnings, and they are classified as unions of symmetrical CT. A case of conjoined twins with thoraco- omphaloischiopagus type is presented here as well as a review of differential diagnosis. The twins had two heads, two pairs of upper limbs and three lower limbs. They also shared thorax, abdomen and pelvis with a single beating heart.
\end{abstract}

Keywords: Conjoined twins; Monozygotic twins; Ambigus genitalia; Surgical separation

\section{Introduction}

The earliest example of conjoined twins returns to a statue which belongs to sixth century, and now is being kept in a museum in Turkey [1]. The first successful attempt to separate conjoined twins occurred in 1689 by fatio [2]. The frequency of thoraco- omphalo-ischiopagus tripus or conjoined twins (CT) is quite rare entity with a estimation of 1 in 50,000 to 100,000 live births [3]. They develop from a single ovum and when the embryonic disc incompletely divides more than 13 days after fertilization [4], and have a strong relation with monoamniotic monochorionic type of placenta. Also there have been some reported attempts to induce conjoined twins experimentally following exposure to a variety of agents, but the ultimate reasons for this phenomenon are not clearly defined. Some studies suggest risk factors such as positive history of genetic talent for conjoined twins in each parent's family, history of drugs for treatment of infertility, or exposure to harmful radiation at the early time of pregnancy are also responsible for the matter.

\section{Case Report}

A 23-year-old woman, gravida 1, para 0 with 14 weeks of amenorrhea visited her radiologist for a routine checkup. The patient had a history of infertility and irregular menstrual periods and failed IUF before her natural pregnancy. She also did not have a history of drug abuse and exposure to environmental teratogen agents. Her husband had nothing positive in his history except a varicocelectomy for correction of abnormal spermatogenesis process. No history of familial congenital abnormalities or twinning was found in the couple. The patient was examined by real-time ultrasonography by her obstetrician and the conjoined twin was already diagnosed for her. She was referred to our hospital and the first diagnosis was confirmed for her. The clinicians advised the patient about likelihood of future outcome, and she accepted termination of pregnancy.

After induction of delivery, the twins were examined. The placenta and its membranes were single. The attachment kind of was thoracoomphalo-ischiopagus. The twins had two heads, two pairs of upper limb and three lower limbs (decephalus, tetrabrachius ,tripus)they also had common thorax, abdomen and pelvic. The external genitalia appeared ambigus. Further evaluation by MRI demonstrated a single heart plus hydrocephalus in one head. Other internal organs were too small for autopsy and imaging evaluation (Figure1 and Figure 2).

\section{Discussion}

As mentioned earlier, the frequency of conjoined twins is estimated of 1 in 50,000 to 100,000 live births, and is believed to be related to a late cleavage of embryonic disk (day 13 and over) after fertilization. Most of conjoined twins report worldwide are females (up to 70-95\%) [3]. Based on a large study in the United States, the incidence of conjoined twins was reported as below: the frequency was estimated 10.25 per million births. The most common types identified were as follows: thoraco omphalopagus (28.4\%), thoracopagus (18.5\%), omphalopagus (9.9\%), parasitic twins $(9.9 \%)$ and craniopagus (6.2\%). The results of the study also suggested that only $60 \%$ of conjoined twins are born alive [3-4]. Furthermore, conjoined twins are often born with higher rates of abnormalities than other babies, thus survival likelihood is lower as the result [5]. Some environmental and genetic factors, such as history of twin and abnormality delivery, exposure to radiation, drugs for

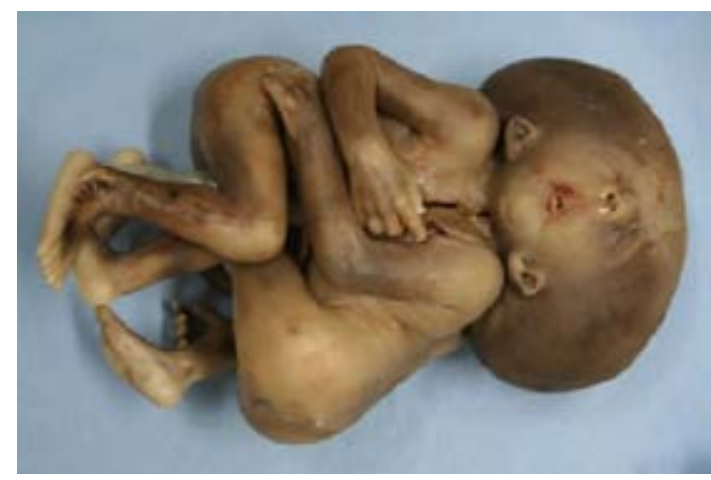

Figure 1: Gross appearance.

*Corresponding author: Shapour Shirani, Assistant professor of Radiology, Department of Radiology, Tehran Heart Center, Tehran University of Medical Sciences, North Kargar Street, Tehran Heart Center, Tehran, Iran, Fax: 0098-21 88029731; E-mail: sh shirani@yahoo.com

Received January 29, 2011; Accepted February 19, 2011; Published February 22, 2011

Citation: Kamalian N, Shirani S, Soleymanzadeh M (2011) Thoraco- OmphaloIschiopagus Tripus Conjoined Twins: Report of a Case. J Forensic Res 2:117. doi:10.4172/2157-7145.1000117

Copyright: (c) 2011 Kamalian N, et al. This is an open-access article distributed under the terms of the Creative Commons Attribution License, which permits unrestricted use, distribution, and reproduction in any medium, provided the original author and source are credited. 


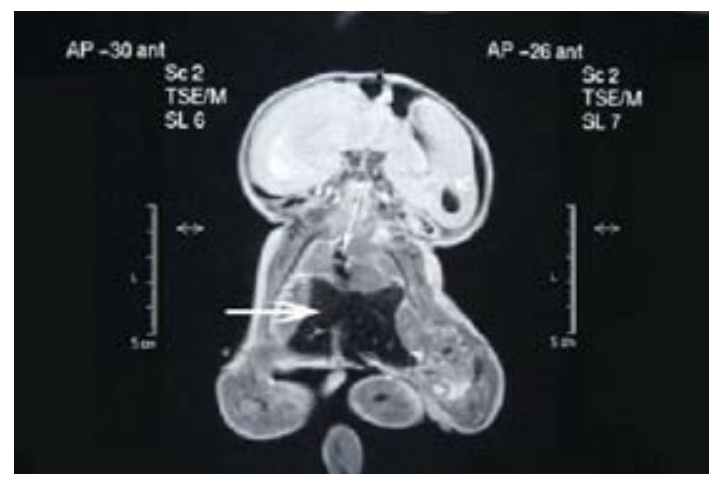

Figure 2: Sagittal T1 MRI of conjoined twins, short arrow dilated occipital horn of hydrocephalic fetus, thin long arrow common heart, thick long arrow common liver.

ovulation induction have been possible causes of conjoined twinning [6].Prenatal diagnosis of conjoined twins is usually performed by ultrasonography, and is confirmed by a more definite imaging method such as MRI. Some important hints that are highly suggestive for conjoined twins are: lack of a separating membrane, detection of other anomalies, multiple $(>3)$ vessels in umbilical cords and fetal bodies are never seen separately on regular sonography visits[7]. Ultrasonography can diagnose CT from the beginning of $12^{\text {th }}$ week of pregnancy, and transvaginal sonography is also capable to detect it even in earlier times[8-9]. Utilization of MRI is also another unique imaging method for confirming ultrasonography findings.MRI technique is highly selective for evaluation the soft tissue defects, such as bladder extrophy , a common findings in CT [10-11]. Early diagnosis of conjoined twins, however is a great help in management of pregnancy and determining delivery technique. Even after live birth, imaging methods play an important role to detect fatal defects, especially in inner organs. Possible separation of conjoined twins should be beard in mind if there are no life-threatening malformations [12]. Such operations usually have good satisfactory outcome unless for shared cardiac chamber or single extrahepatic billiary tree.

\section{References}

1. Geroulanos S, Jaggi F, Wydler J, Lachat M, Cakmakci M (1993) Thoracopagus symmetricus. On the separation of Siamese twins in the 10th century A. D. by Byzantine physicians. Gesnerus 50: 179-200.

2. Rickham PP (1986) The dawn of paediatric surgery: Johannes Fatio (16491691): his life, his work and his horrible end. Prog Pediatr Surg 20: 94-105.

3. Edmonds LD, Layde PM (1982) Conjoined twins in the United States, 19701977. Teratology 25: 301-308.

4. Rudolph AJ, Michaels JP, Nichol BL (1967) Obstetric management of conjoined twins. Birth Defects 3: 1-28.

5. Smith DW (1982) Recognizable patterns of human malformation: Genetic embryologic and clinical aspects. Third Edition. Major Probl Clin Pediatr 7: $1-653$.

6. Ferm VH (1969) Conjoined twinning in mammalian teratology. Arch Environ Health 19:353-357.

7. Koontz WL, Herbert WN, Seeds JW, Cephalo RC (1983) Ultrasonography in the antepartum diagnosis of conjoined twins: A report of two cases. J Reprod Med 28: 627-630.

8. Pajkrt E, Jauniaux E (2005) First-trimester diagnosis of conjoined twins. Prenat Diagn 25: 820-826.

9. Vural F, Vural B (2005) First trimester diagnosis of dicephalic parapagus conjoined twins via transvaginal ultrasonography. J Clin Ultrasound 33: 364 366.

10. Martínez L, Fernández J, Pastor I, García-Guereta L, Lassaletta L, et al (2003) The contribution of modern imaging to planning separation strategies in conjoined twins. Eur J Pediatr Surg 13: 120-124.

11. Mackenzie TC, Crombleholme TM, Johnson MP, Schnaufer L, Flake AW, et al. (2002) The natural history of prenatally diagnosed conjoined twins. J Pediatr Surg 37: 303-309.

12. Hoyle RM (1990) Surgical separation of conjoined twins. Surg Gynecol Obstet 170: 549-562. 